\title{
Evidence for a positive environment for hospital pharmacy in the European Union to design, advocate and implement local healthcare policy
}

\author{
David Gerrett, ${ }^{1}$ David Preece ${ }^{2}$
}

${ }^{1}$ Patient Safety Domain, NHS England, London, England ${ }^{2}$ European Association of Hospital Pharmacists, Brussels, Belgium

Correspondence to Dr David Gerrett, 16B Wood Lane, Horsley Woodhouse DE7 $6 \mathrm{BN}, \mathrm{UK}$;

david.gerrett@nhs.net

Received 8 August 2014 Accepted 11 August 2014

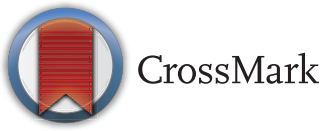

To cite: Gerrett $D$,

Preece D. Eur J Hosp Pharm 2014;21:288-290.

\section{ABSTRACT}

The first survey of its kind sought to determine if the environment of hospital pharmacy was conducive to the design, advocacy and implementation of healthcare policy to make healthcare and the use of medicines safer and more effective for patients. It was undertaken within EAHP member countries between November 2013 and February 2014. This was part of the preparatory work for the European Association of Hospital Pharmacists' initiative to produce European Union Statements on Hospital Pharmacy in May 2014. The results were communicated at the event to provide contextualisation prior to discussion on Statements. The survey form asked questions based on meeting 10 published preconditions for successful implementation of policy. Proximity of hospital pharmacists to key decision makers, the capacity to communicate the intent of policy, being given the authority to control budgets and actions to implement the outcomes of policy were all surveyed. In addition, the impact of barriers and the nature of services that had been compromised were quantitatively and qualitatively described. From the responses, hospital pharmacy appears in a very strong position to devise and implement new policies for the benefit of patients; however, there is ever present tension between service and resource, which has constrained development and that will need to be overcome if improvements are to be made. Ensuring that healthcare policies concerning medicines and associated services are politically, ideologically, ethically, financially and socially acceptable while being capable of local implementation is seen as critical to success. Pharmacy appears well placed to undertake this challenge.

\section{INTRODUCTION}

The European Association of Hospital Pharmacists' (EAHP) Statements ${ }^{1}$ provide focus and guidance for the evolution of hospital pharmacy, which has been sanctioned by a wide stakeholder audience. For each statement to impact on patient care the general intent must be translated into dedicated local action. It is not possible for national organisations to account for the variation in local environments in terms of prescriptive generalisable policies; rather those healthcare practitioners working directly with service must work transparently and collectively to determine the blueprints for local activity.

The complexity of this is increased as Statements have to be further contextualised within government structures, strategies and funding systems. Challenges abound as hospital pharmacists as professionally registered healthcare professionals work to reconcile the patient-facing actions arising from Statements in the context of country-specific, unique political and policy constraints.

Thus, in order to bring about the implementation of local policy and provide to patients the actions that are underpinned by the Statements, policies must be couched in a politically, ideologically, ethically, financially and socially acceptable manner. Our understanding of the necessary preconditions for successful policy implementation was crystallised by Gunn, professor of Civil Service Administration at Strathclyde University in the late 1970s, who published the following 10 prerequisites:

1. That circumstances external to the implementing agency do not impose crippling constraints.

2. That adequate time and sufficient resources are made available to the programme.

3. That not only are there no constraints in terms of overall resources but also that, at each stage in the implementation process, the required combination of resources is actually available.

4. That the policy to be implemented is based upon a valid theory of cause and effect.

5. That the relationship between cause and effect is direct and that there are few, if any, intervening links.

6. That there is a single implementing agency which need not depend upon other agencies for success or, if other agencies must be involved, that the dependency relationships are minimal in number and importance.

7. That there is complete understanding of, and agreement upon, the objectives to be achieved; and that these conditions persist throughout the implementation process.

8. That in moving towards agreed objectives it is possible to specify, in complete detail and perfect sequence, the tasks to be performed by each participant.

9. That there is perfect communication among, and co-ordination of, the various elements involved in the programme.

10. That those in authority can demand and obtain perfect obedience.

While Gunn's 10 preconditions are unlikely to be fully satisfied for any one policy, there is an implicit understanding that the more points a policy manages to satisfy, the more it is likely to succeed. There are clear implications for the working environment of hospital pharmacy practitioners if they are to be in a position to deliver on the implementation agenda of the Statements. For Gunn's points:

- 6,9 and 10: hospital pharmacists must have close access to those in power to make 
Table 1 Proximity of chief pharmacist to the highest level of authority

\begin{tabular}{|c|c|c|c|c|c|c|c|c|c|c|}
\hline Proximity & 0 & 1 & 2 & 3 & 4 & 5 & 6 & 7 & (blank) & Total \\
\hline \multirow[t]{2}{*}{ Count } & 4 & 155 & 162 & 47 & 10 & 6 & 1 & 1 & 24 & 410 \\
\hline & $1.0 \%$ & $37.8 \%$ & $39.5 \%$ & $11.5 \%$ & $2.4 \%$ & $1.5 \%$ & $0.2 \%$ & $0.2 \%$ & $5.9 \%$ & $100.0 \%$ \\
\hline
\end{tabular}

Question: In the hierarchy of management how many level(s) are there between the person in charge of the hospital and the most senior pharmacist directly involved with the hospital pharmacy service?

decisions. The more 'links in the chain of authority' the more accurate communication can be compromised.

- 1, 2 and 3: hospital pharmacists must be given command over the resources to enact policy and implement services. Ideally, these resources should include the medicines budget, the pharmacy service itself and services that impact on safe, effective drug usage.

- 4, 5, 6, 7, 8, 10: hospital pharmacists must be trusted as professionals to 'know their job' in determining the right 'new' policy and to be in charge of the process of its implementation.

Following two formal EAHP meetings, and with no existing relevant information available, a survey was considered useful to determine whether or not hospital pharmacists in Europe were currently in a working environment and situation to translate the Statements into local policies and finally into services that might impact positively on patients.

\section{METHODS}

A set of survey instrument questions was devised, piloted and then made accessible online in Survey Monkey. A letter describing the intention of the survey was sent to the EAHP representative of each of the EAHP member countries, inviting them to identify suitable hospital pharmacists for completion of the survey. The instrument contained a mixture of closed and open statements with quantitative and qualitative options, respectively. All responses were downloaded in raw Excel format from Survey Monkey and inspected (DG) for internal consistency and reliability. No formal statistical analysis was performed.

\section{RESULTS}

The survey was open for responses from 22 November 2013 to 12 February 2014 and collected 535 responses from 34 EU member states. Detailed review of each response identified 410 for assessment. Incomplete responses and nonsensical entries accounted for the difference. Limited responses were received from Turkey (1), Romania (1), Lithuania (1), Latvia (2), Spain (3), Poland (3), Malta (3), Luxembourg (3), Bosnia and Herzegovina (3) and Denmark (4). Iceland (3) was making preparations for EU membership and its responses were included in the assessment. All other EAHP member countries provided five or more responses which was the target for the survey. Tables 1-7 present the quantitative responses and redacted questions. The full survey is available from DG on request.

Table 2 Control of the medicines budget

\begin{tabular}{llllll}
\hline Percentage & $\mathbf{0 - 5 0 \%}$ & $>\mathbf{5 0 - 9 0 \%}$ & $\mathbf{> 9 0 \%}$ & (blank) & Total \\
\hline Count & 60 & 41 & 268 & 41 & 410 \\
& $15 \%$ & $10 \%$ & $65 \%$ & $10 \%$ & $100 \%$
\end{tabular}

Question: Estimate what percentage (\%) of the total annual expenditure on medicines purchased by your hospital is directly controlled by your hospital pharmacy department.
Responses to the open dialogue boxes provided a rich understand of the underlying themes for submitted responses. They describe a depressing litany of services for patients that should have been provided but had to be curtailed, which included: implementing an IT system for anticoagulation, axing of clinical services, evaluation of infusions for quality assurance, delivery of an antimicrobial stewardship programme, greater involvement in oncology chemotherapy prescribing and screening, and deliverance of pharmacy produced products in the evening after 18:00.

Qualitative descriptions were uniform in describing the tensions between provision of a quality service and available resources. It was clear that hospital pharmacists currently are advocates of the former and battle the latter with what skills and authority they possess.

\section{DISCUSSION}

Limitations of this survey include: respondents were asked to recall and estimate the frequency of events, then provide simplifications of complex situations; there was no triangulation or validation of response, however, data cleansing was undertaken; and Gunn's preconditions have not, to the author's knowledge, been tested in the pharmacy environment.

From the survey we found $77 \%$ of hospital chief pharmacists are line managed by only one or two people. As such we are reassured that local policies can be taken by pharmacy and discussed at the highest level of authority. It is understood that control over the budget is a fundamental requirement for implementing any policy. ${ }^{3}$ That $90 \%+$ of the budget is controlled by $65 \%$ of respondents provided evidence that hospital pharmacy is in a strong position. While hospital pharmacy works collectively and collaboratively with the range of healthcare professionals using medicines, where money flows there is power of influence.

Given this responsibility, it was surprising to find that so many $(40 \%)$ had control of less than $50 \%$ of the total cost of pharmacy services. Nevertheless, some countries have a minimum level of staffing and with continued EU harmonisation it is expected that there will be pressure for variation in staffing to normalise.

We found that in $64 \%(n=410)$ of cases the hospital pharmacy was given 'shared', 'most' or 'total' authority to introduce a new service. We can say that hospital pharmacy has a track record of being trusted by organisations to bring about new services. Being able to communicate the intent of a new service is key and in $63 \%$ of cases the general hospital management understood what was required to implement a new service 'somewhat', 'mostly' or 'completely'.

Table 3 Control of pharmacy as a service

\begin{tabular}{llllll}
\hline Percentage & $\mathbf{0 - 5 0 \%}$ & $\mathbf{> 5 0 - 9 0 \%}$ & $>\mathbf{9 5 \%}$ & (blank) & Total \\
\hline Count & 162 & 105 & 91 & 52 & 410 \\
& $40 \%$ & $26 \%$ & $22 \%$ & $13 \%$ & $100 \%$ \\
\hline
\end{tabular}

Question: What percentage (\%) of the total cost of pharmacy services is directly controlled by pharmacy? 
Table 4 Delegated authority

\begin{tabular}{|c|c|c|c|c|c|c|c|}
\hline Percentage & $\begin{array}{l}\text { The hospital } \\
\text { pharmacy was given } \\
\text { no authority }(0 \%)\end{array}$ & $\begin{array}{l}\text { The hospital pharmacy } \\
\text { was given limited } \\
\text { authority }(25 \%)\end{array}$ & $\begin{array}{l}\text { The hospital pharmacy } \\
\text { was given shared } \\
\text { authority }(50 \%)\end{array}$ & $\begin{array}{l}\text { The hospital pharmacy } \\
\text { was given most } \\
\text { authority }(75 \%)\end{array}$ & $\begin{array}{l}\text { The hospital pharmacy } \\
\text { was given total } \\
\text { authority }(100 \%)\end{array}$ & (blank) & Total \\
\hline \multirow[t]{2}{*}{ Count } & 23 & 36 & 96 & 119 & 48 & 88 & 410 \\
\hline & $6 \%$ & $9 \%$ & $23 \%$ & $29 \%$ & $12 \%$ & $21 \%$ & $100 \%$ \\
\hline
\end{tabular}

Question: The last time your hospital pharmacy planned to introduce a new service, how much authority was the hospital pharmacy given over how this was to be done?

Table 5 Communication of intent

\begin{tabular}{lllllll}
\hline Percentage & $\begin{array}{l}\text { The management of } \\
\text { the hospital did not } \\
\text { understand at all } \mathbf{( 0 \% )}\end{array}$ & $\begin{array}{l}\text { The management of } \\
\text { the hospital } \\
\text { understood a little } \\
\mathbf{( 2 5 \% )}\end{array}$ & $\begin{array}{l}\text { The management of } \\
\text { the hospital } \\
\text { understood somewhat } \\
\mathbf{( 5 0 \% )}\end{array}$ & $\begin{array}{l}\text { The management of } \\
\text { the hospital mostly } \\
\text { understood } \mathbf{( 7 5 \% )}\end{array}$ & $\begin{array}{l}\text { The management of } \\
\text { the hospital completely } \\
\text { understood (100\%) }\end{array}$ & $\begin{array}{l}\text { (blank) } \\
\text { Total }\end{array}$ \\
\hline \multirow{2}{*}{ Count } & 10 & 54 & 78 & 128 & 54 & 86 \\
& $2 \%$ & $13 \%$ & $19 \%$ & $31 \%$ & $13 \%$ & 410 \\
\hline
\end{tabular}

Question: The last time your hospital pharmacy provided a significant new service, to what extent did the general hospital management understand what was required to implement the service successfully?

Based on meeting Gunn's preconditions, the survey questions sought to determine whether pharmacy was in a position to undertake policy implementation. The response provided very positive indications that pharmacy is in a strong environmental position to deliver and implement policy.

Yet we found that $81 \%(n=410)$ of hospital pharmacy departments were constrained in continuing to provide one or more patient-orientated services or develop a new one(s), due to insufficient resources. Hospital pharmacy is attempting to maintain or improve services but is fighting the challenge of capped resources. As advocates for patients and as healthcare professionals they will continue to make the case for change and improvement, but the loss of critical clinical and quality services was disheartening. The impact of barriers is sorely felt and qualitatively confirmed to be financial at heart. The following quote encapsulates the dilemma:

If you can make more money with the innovation then you'll get it. Also, if you can prove that you can prevent more costs (liability for negligence) or if a process will be quicker (you produce a mixture of a medicine what allows the doctor to be 10 minutes faster in operating room).

Table 6 Resource as a limitation

\begin{tabular}{lllllll}
\hline Number of times & $\mathbf{0}$ & $\mathbf{1}$ to $\mathbf{5}$ & $\mathbf{> 5}$ to $\mathbf{4 4}$ & $\mathbf{> 5 2}$ & (blank) & Total \\
\hline Count & 79 & 156 & 40 & 29 & 106 & 410 \\
& $19 \%$ & $38 \%$ & $10 \%$ & $7 \%$ & $26 \%$ & $100 \%$ \\
\hline
\end{tabular}

Question: To the best of your knowledge, in the last year, how many times was your hospital pharmacy department unable to continue to provide a service or develop a new one, due to insufficient resources?
There are over 25000 hospital pharmacists in the EU and many more hospital pharmacy technicians. Virtually all hospitals have a discrete pharmacy department and each EU member state has professional bodies; associations like EAHP have specific networks and mechanisms for contact. It is anticipated that this resource, with EAHP backing and tutorage, will now swing behind implementation of the Statements.

This is the first study of its kind. It has shown that the process of policy implantation is not a barrier to success. Whatever is said and done by governments and managers, policies are decided at the forefront of practice. ${ }^{4}$ We believe that hospital pharmacists can meet the challenges and that as vocational professionals, will respond to the Statements to successfully implement local policy initiatives because at heart hospital pharmacists want to make healthcare and the use of medicines safer and more effective for patients.

Acknowledgements The help and support of Roberto Frontini (EAHP President), Jennie De Greef (Chief Operating Officer) and Richard Price (Policy and Advocacy Officer) in assisting with this work is acknowledged.

Competing interests None.

Provenance and peer review Commissioned; internally peer reviewed.

\section{REFERENCES}

1 European Association of Hospital Pharmacists. New European statements of hospital pharmacy agreed by patients, healthcare professional and hospital pharmacists. EAHP, 2014. http://www.eahp.eu/events/european-summit/summit-documents (accessed 8 Aug 2014).

2 Gunn L. Why is implementation so difficult? Manag Serv Govt 1978:169-76.

3 Widavsky A. Analysis as art. In: Widavsky A. ed. The art and craft of policy analysis. London: The Macmillan Press, 1980.

4 Lipsky M. Street-level bureaucracy: dilemmas of the individual in public services. New York: Russell Sage Foundation, 1980.

Table 7 The impact of barriers

\begin{tabular}{|c|c|c|c|c|c|c|c|}
\hline Percentage & $\begin{array}{l}\text { Barriers do not prevent } \\
\text { improvements or no } \\
\text { barriers }(0 \%)\end{array}$ & $\begin{array}{l}\text { Barriers prevent } \\
\text { improvements a little } \\
(25 \%)\end{array}$ & $\begin{array}{l}\text { Barriers prevent } \\
\text { improvements } \\
\text { somewhat }(50 \%)\end{array}$ & $\begin{array}{l}\text { Barriers prevent } \\
\text { improvements to a } \\
\text { great extent }(75 \%)\end{array}$ & $\begin{array}{l}\text { Barriers make } \\
\text { improvements } \\
\text { impossible }(100 \%)\end{array}$ & (blank) & Total \\
\hline \multirow[t]{2}{*}{ Count } & 8 & 33 & 97 & 146 & 32 & 94 & 410 \\
\hline & $2 \%$ & $8 \%$ & $24 \%$ & $36 \%$ & $8 \%$ & $23 \%$ & $100 \%$ \\
\hline
\end{tabular}

